\title{
Mafic rocks from Erinpura gneiss terrane in the Sirohi region: Possible ocean-floor remnants in the foreland of the Delhi Fold Belt, NW India
}

\author{
M K PANdit ${ }^{1, *}$, H DE WAlL ${ }^{2}$, H Daxberger ${ }^{2}$, J Just ${ }^{2}$, \\ M BESTMANN ${ }^{2}$ and K K SHARMA ${ }^{3}$ \\ ${ }^{1}$ Department of Geology, University of Rajasthan, Jaipur 302004 , India. \\ ${ }^{2}$ GeoZentrum Nordbayern, Universität Erlangen-Nürnberg, Schlossgarten 5, D-91054 Erlangen, Germany. \\ ${ }^{3}$ Department of Geology, Govt. PG College, Sirohi 307 001, India. \\ *e-mail: manoj.pandit@gmail.com
}

\begin{abstract}
A small isolated mafic body occurs to the south of Sirohi near village Daba within the Neoproterozoic Erinpura Granite in the southern sector of the Proterozoic Delhi Fold Belt in NW India. This mafic body occurs close to a 100 m wide NE-SW trending shear zone (Daba Shear Zone) which overprints the felsic rock fabrics. Further south, a small mafic body near village Kui was also sampled which forms the southern limit of the Phulad Ophiolite Suite which is a $300 \mathrm{~km}$ long major NE-SW trending lineament, described as Western Margin Fault. Some of the lithological components of the Daba mafic body show locally preserved magmatic fabric but completely transformed mineralogies under lower amphibolites facies metamorphic conditions where two-stage deformation has been inferred. Magnetic fabric analysis underlines a general correspondence of structural elements in both felsic and mafic lithologies. Binary correlations of $\mathrm{Zr}$ with other high field strength elements underline fractionation as the main process in the evolution of Daba and Kui rocks. Geochemical characteristics indicate subalkaline tholeiitic basalt affinity for these mafic rocks. The trace element characteristics, such as enriched LIL elements, high $\mathrm{Th}$, absence of negative $\mathrm{Nb}$ anomalies and depletion in compatible elements in Daba samples suggest an enriched mantle source and lower degree of melting. The trace and rare earth element characteristics for Kui (Th anomaly, Nb-Ta trough and less spiked patterns, flat REE trends) indicate derivation from a refractory mantle source affected by fluids derived from subduction. Distinct differences in trace and REE characteristics between Daba and Kui can be interpreted in terms of different stages of ophiolite development.
\end{abstract}

\section{Introduction}

The NW Indian terrane archives a welldocumented record of Precambrian geology, from Archean basement and overlying Proterozoic Fold Belts (Gupta et al 1997) to the Eocambrian Marwar Basin (Pareek 1984; Pandit et al 2001) (figure 1a). The oldest rock unit in this region is the 3.3 to $2.5 \mathrm{Ga}$ Banded Gneiss Complex which forms the basement for the Proterozoic supracrustal Aravalli and Delhi fold belts (Roy and Kröner 1996; Wiedenbeck et al 1996). These Proterozoic sequences have undergone green-schist to amphibolite facies metamorphism and show evidence of multiple deformation episodes between 1.8 and $1.4 \mathrm{Ga}$ (Roy and Jakhar 2002). The southern

Keywords. Daba mafic rocks; geochemistry; magnetic fabric; neoproterozoic; Phulad ophiolite; NW India. 


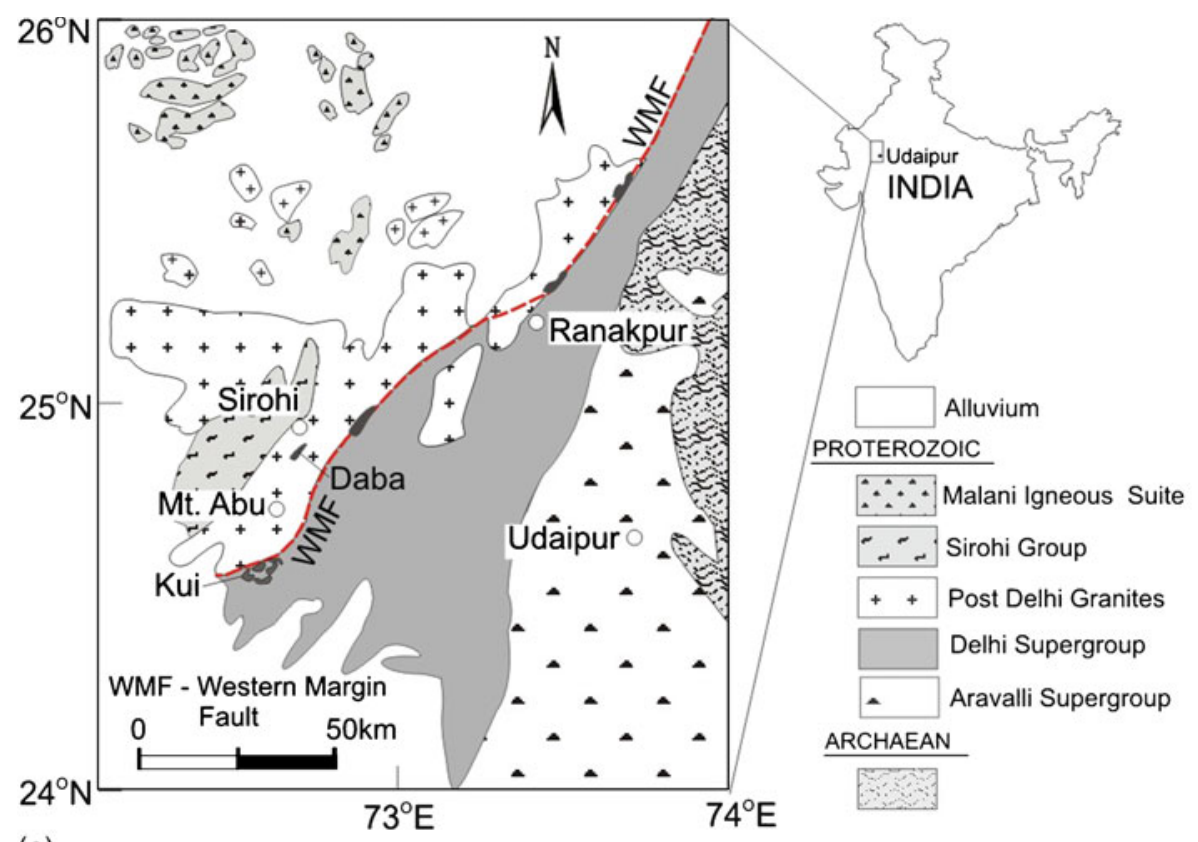

(a)

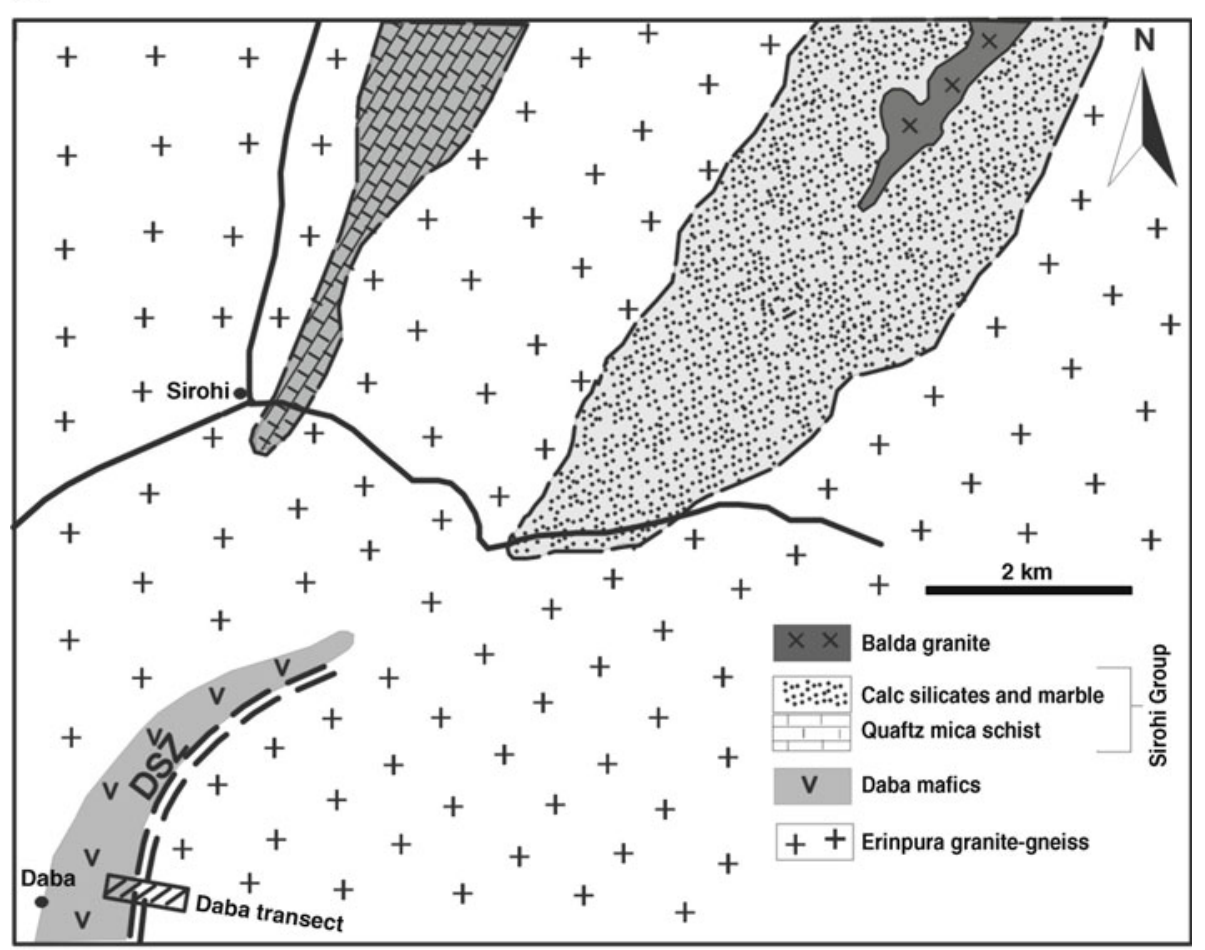

(b)

Figure 1. (a) Simplified geological map of NW India showing major Precambrian units and ophiolite occurrences along the Western Margin Fault (WMF). Map adapted from Heron (1953), Gupta et al (1980), Roy and Jakhar (2002) and Just et al (2011). (b) Lithostratigraphic map (adapted from Roy and Sharma 1999) showing occurrence of the Daba mafic body within Erinpura granite terrane around Sirohi (SW Rajasthan). Sampled section along NW-SE traverse is also shown.

sector of the Delhi Fold Belt (DFB) represents a Grenvillian age $(\sim 1 \mathrm{Ga})$ arc terrane which also corresponds with the period of amalgamation of crustal blocks to form the Rodinia supercontinent (Dalziel 1991; Meert and Torsvik 2003; Li et al 2008). The western margin of the DFB is defined by a linear zone of ductile shearing (Ghosh et al
1999), named as Western Margin Fault (WMF) which is interpreted as a Proterozoic suture (Gupta et al 1980).

Occurrence of isolated outcrops of maficultramafic rocks (peridotite - gabbro-pyroxenite, gabbro-norite, anorthosite and sheeted dykes) along a $300 \mathrm{~km}$ long and $20-50 \mathrm{~km}$ wide zone 
along the WMF further substantiate the status of this lineament as a major structure (suture zone?). These mafic-ultramafic rocks have been identified as remnants of 'ophiolite', named as Phulad Ophiolite Suite (POS - Gupta et al 1980). The Sm-Nd isochron age of $1024 \pm 78 \mathrm{Ma}$ (Volpe and Macdougall 1990) for the Ranakpur diorites from the POS is in general agreement with coeval arc magmatism in this terrain (987 $\pm 6 \mathrm{Ma}$, Deb et al 2001; 968.3 \pm 1 Ma, Pandit et al 2003). The WMF, also called Phulad Shear Zone in this southern sector of Delhi Fold Belt, is characterized by distinctly vertical stretching lineations (Ghosh et al 1999) and the kinematics is identified as a transpressional setting (Sengupta and Ghosh 2004). This fault zone also bears evidence of reactivations, however, their timing has not been constrained so far (Biswal et al 2004; Sarkar and Biswal 2005). The terminal stage of Delhi orogeny is marked by felsic magmatism [late syn- to post-orogenic granites and granodiorite, named 'Erinpura Granite' (Heron 1953)], ubiquitous in the southern sector of the Delhi Fold Belt and its western foreland. The Erinpura Granite is an ensemble of variably deformed granite and granite gneisses (Gupta et al 1997) which bears evidence of anatexis and shearing (Just et al 2011). The Erinpura thermal event is also noted as isotopic resetting in the ophiolites and Delhi Fold Belt arc sequences (Volpe and Macdougall 1990).

Within the Erinpura granite terrane, a small mafic body occurring to the south of Sirohi town was reported by Roy and Sharma (1999) from the village Daba (figure 1b). This isolated mafic body is juxtaposed to a NE-trending shear zone (Daba Shear Zone) within the Erinpura granite terrain. The Daba mafic rocks, for which no petrographic or geochemical data are available so far, occur to the west of the reported mafic-ultramafic rocks of the Phulad Ophiolite Suite (Gupta et al 1980). Geochemical characteristics of the Phulad mafic rocks identify them as ocean floor and low-K tholeiites (Volpe and Macdougall 1990; Khan et al 2005). The Daba mafic rocks are genetically unrelated to the Erinpura Granites or the Delhi Supergroup metasediment hosts. These mafic rocks need to be evaluated for petrogenetic aspects and for a possibility whether they represent remnants of an ocean floor, analogous to the Phulad Ophiolite Suite exposed in the same Neoproterozoic terrane.

We have studied the area around Daba in the southern Delhi Fold Belt (figure 1a, b) and the results are presented in this paper. The aim of the paper is:

- to infer the deformation kinematics of the shear zone in Daba and its relationship with mafic and felsic rocks through geological characterization, and

- geochemical evaluation of the mafic rocks from Daba and Kui for petrogenetic interpretation and possible correlation with POS.

For this purpose we have sampled the Daba Shear Zone $\left(24^{\circ} 50.459^{\prime} \mathrm{E}\right.$ : $\left.72^{\circ} 51.061^{\prime} \mathrm{E}\right)$ along a NW-SE traverse and documented the field data (figures 1b, 2). In addition, mafic rock samples from Kui
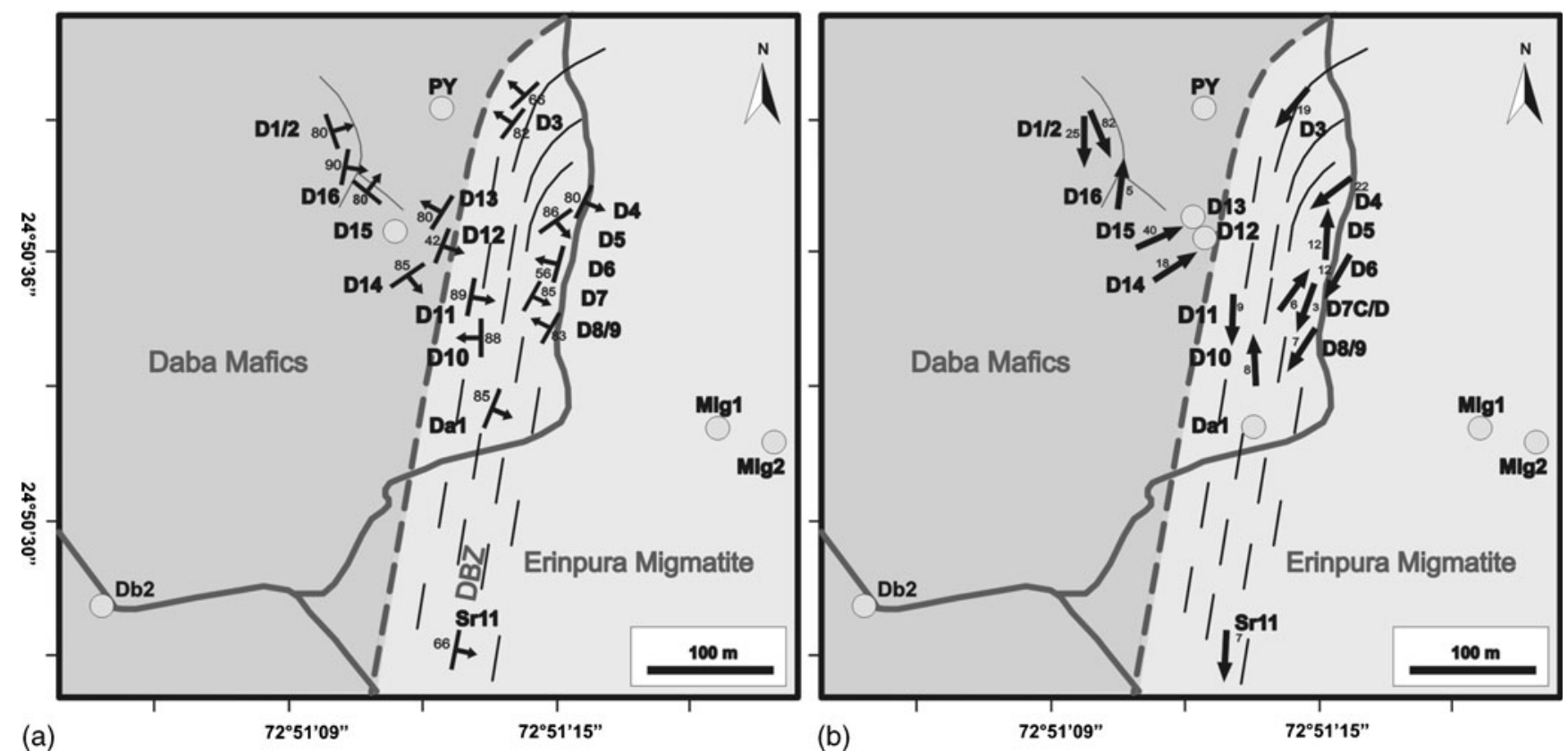

Figure 2. Map showing sample locations and orientations of structural elements in the studied section across the Daba Shear Zone (DBZ). (a) Foliations, and (b) lineations. 
$\left(24^{\circ} 27 . \quad 696^{\prime} \mathrm{N}: \quad 72^{\circ} 48.205^{\prime} \mathrm{E}\right)$ representing the southern part of POS (Biswal et al 2004; Khan et al 2005) were also collected and analyzed for comparison with the Daba mafic rocks.

\section{The Daba mafic body}

The Daba mafic body is traceable over a distance of $3 \mathrm{~km}$ within the Erinpura Granite terrane in the south of Sirohi (figure 1b, see also Roy and Sharma 1999). The 860-830 Ma Erinpura Granite terrane (Choudhary et al 1984; Just et al 2011) was uplifted after the Delhi orogeny and formed the basement for sedimentation of pelitic and carbonate sequences of the Sirohi Group (figure 1b). The age of these sediments is not properly constrained; however, they are overlain by volcano-sedimentary sequence called Sindreth Group in which felsic volcanics have been precisely dated at $767 \mathrm{Ma}$ (zircon $\mathrm{U}-\mathrm{Pb}$ ) by van Lente et al (2009). Erinpura Granite and Sirohi Group rocks share a common deformation history, characterized by NE-SW trending foliations and map-scale fold structures in the so called 'Sirohi Belt' (Roy and Sharma 1999). Shear bound slivers of Sirohi Group taper towards the south, however, the southern boundary is not well defined due to sand cover and lack of rock exposures. In SE continuation of the Sirohi belt some outcrops can be seen to the east of village Daba (south of Sirohi) where a $>100 \mathrm{~m}$ wide zone with NE-SW trending vertical foliations has been identified as a shear zone and named as Daba Shear Zone (DSZ).

We undertook a NW-SE traverse (figures 1b, 2) beginning with coarse grained non-sheared Erinpura

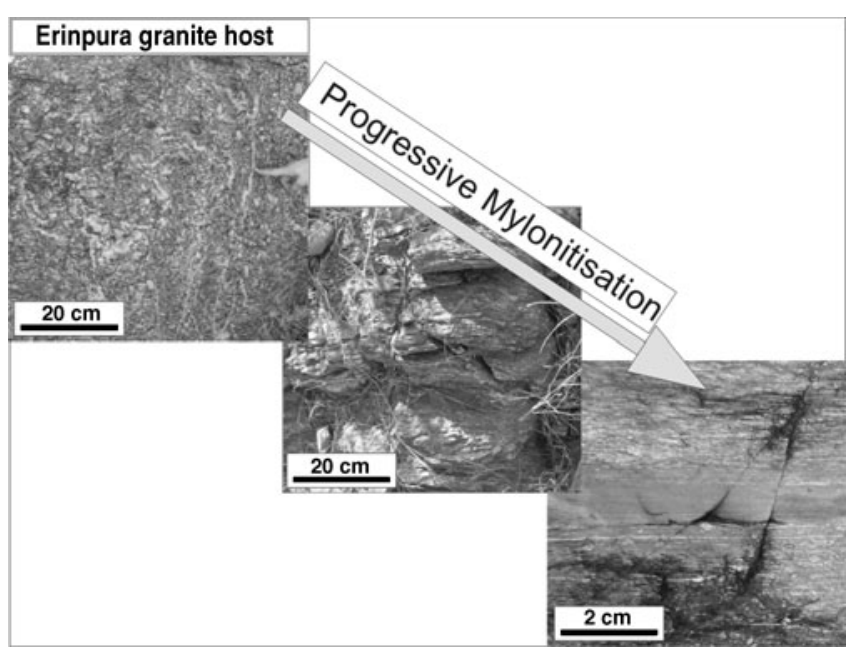

Figure 3. Field photographs showing fabric transformation of host anatectic Erinpura granite gneiss into mylonitic and ultra-mylonitic shear fabrics in the Daba Shear Zone. granite-gneiss through its sheared and mylonitized counterparts. The non-sheared granite-gneiss shows incipient migmatitization and localized anatexis (figure 3) as compared to large-scale partial melting seen in the area further north-east (Just et al 2011). At the contact between sheared Erinpura Granite (felsic mylonites) and Daba mafic body, a thin band (few dm) of garnet mica-schist occurs.
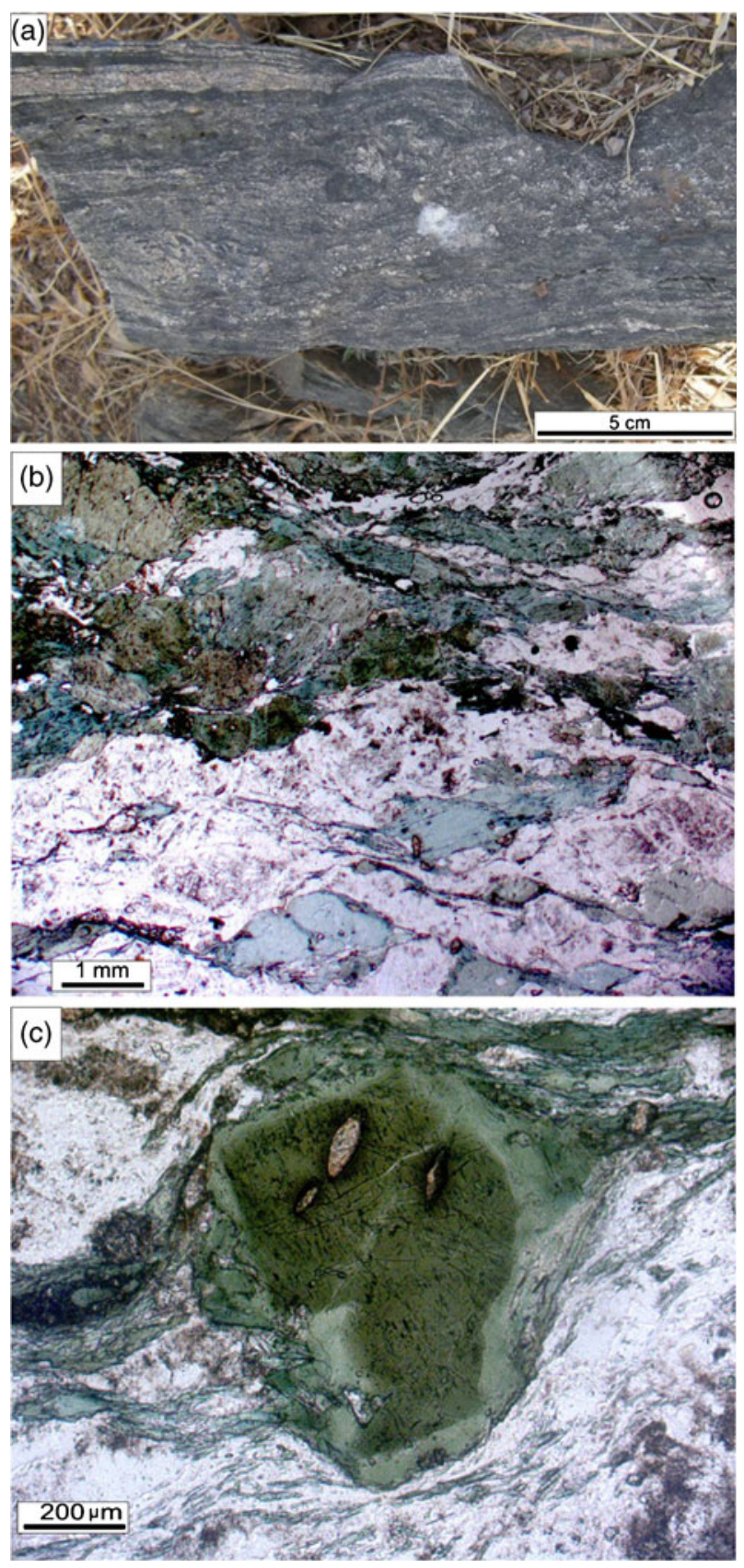

Figure 4. (a) Daba mafic rock showing alternate plagioclaserich and hornblende-rich bands defining a pronounced foliation. (b-c) Photomicrographs showing features of shear deformation that can be used to infer the kinematics of the shear zone; (b) sigmoidal fabrics and development of shear planes in mafic and felsic parts; and (c) asymmetric wings indicating synkinematic recrystallisation of hornblende clasts during shearing. 
The Daba mafic rocks show megascopic variation from massive to foliated types wherein the generally steep foliations show meter-scale anastomosing pattern around the more rigid massive parts. Cmscale features of intense shearing are seen only in the feldspar-rich parts. In the sheared felsic rocks subhorizontal stretching lineations (figure $2 \mathrm{~b}$ ) are defined by elongated quartz and feldspar grains. Shear-induced rotation of porphyroclasts and development of s-c fabrics have been considered for kinematic analyses of the shear movement. These features are seen in the felsic mylonites and ultramylonites as well as in the feldspar-rich zones within the mafic rocks (figure $4 \mathrm{a}$ ). There kinematic analysis identifies the shear zone as a zone of dextral strike-slip movement. Deformation conditions can be inferred from the microstructures and stability of mineral phases present. Major mineral phases in the felsic mylonites are plagioclase, $\mathrm{K}$-feldspar, quartz and biotite. Feldspar is often fractured and shows features of low-temperature plasticity, such as undulose extinction, furthermore deformation twinning and marginal recrystallisation (core-mantle structures) have been recognized. Deformation induced exsolution (perthitic structures) can be seen in K-feldspar. Quartz is completely recrystallized through a predominant subgrain rotation. Stretching lineations are also locally seen in the sheared feldspar-rich parts of mafic rocks. This is marked by the tails of recrystallized hornblende (figure 4b, c). Earlier formed brownish-green hornblende, with fine inclusions along the cleavage planes and larger inclusions of sphene, is seen recrystallizing into clear green hornblende during deformation (figure 4c). Asymmetric tails of newly formed green hornblende indicate shear facilitated recrystallization. Stability of biotite in felsic and green hornblende in mafic rocks indicate deformation under lower amphibolite facies metamorphic conditions.

Massive, non-sheared parts of the Daba mafic rocks show gabbroidic appearance and locally a megacrystic type is seen (figure 5a). This variety consists of large (cm size) equigranular, megacrysts $(>75 \%)$ of hornblende set in a groundmass consisting of sericitized plagioclase, hornblende and epidote (figure 5b). Relict pyroxene cores mantled by hornblende, allow its nomenclatures as metapyroxenite. Hornblende is also present as the main mineral in the medium- and fine-grained types. The Daba mafic rocks comprise hornblende, chlorite, actinolite, sericitized plagioclase and epidote, indicating obliteration of primary magmatic mineralogy. Two stages of alteration can be inferred from petrographic analysis. In the first stage sericitization of plagioclase and transformation of pyroxene into green-brown hornblende occurred. An overprint under retrograde temperature conditions
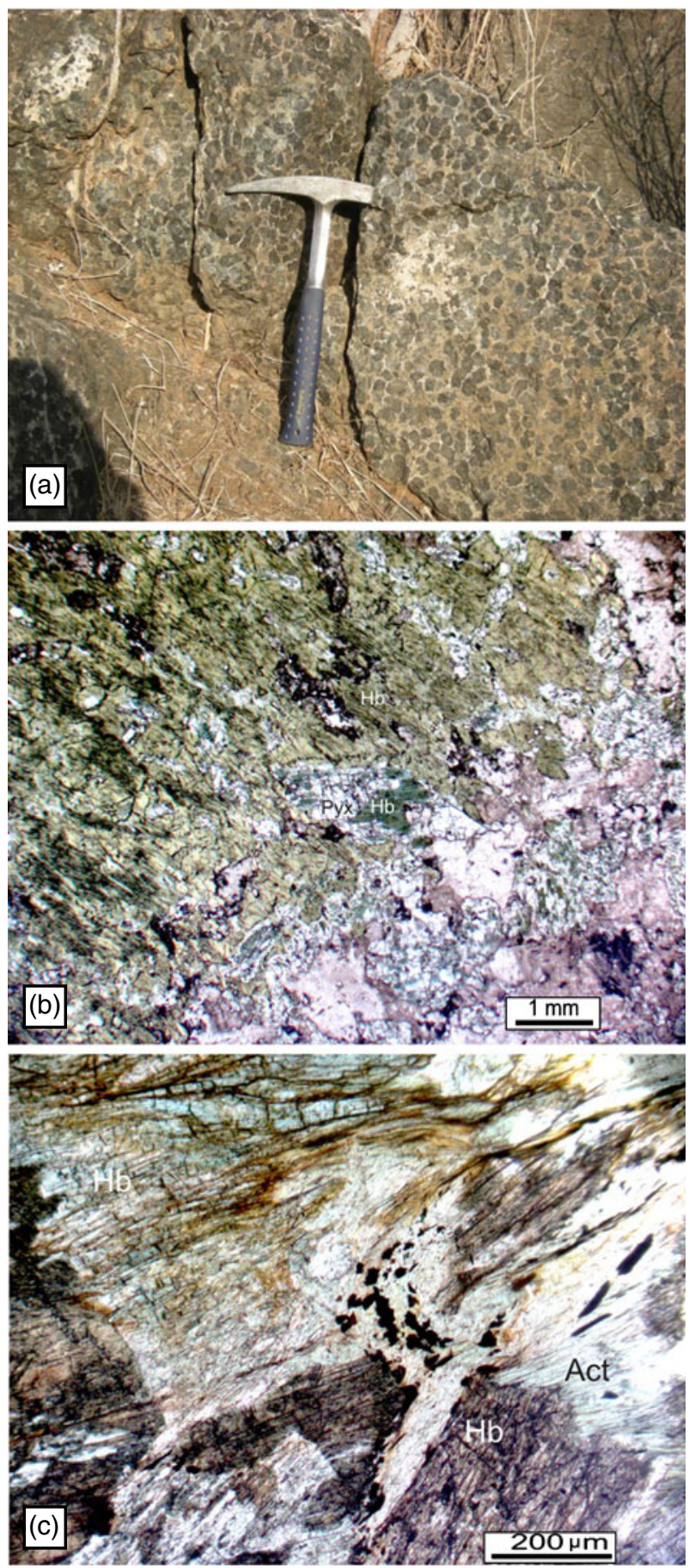

Figure 5. (a) Photograph of meta-pyroxenite showing equigranular, subhedral mafic minerals set in a finergrained felsic rich groundmass. (b) First stage alteration in Daba metapyroxenite seen as alterantion of pyroxene into green-brown hornblende. Relict pyroxene can still be seen. (c) Transformation of brown-green hornblende into actinilite during second stage of alteration.

during the shear deformation is indicated by the synkinematic growth of inclusion-free green hornblende which marks the second stage of deformation. This later stage of retrogression under the influence of fluids was, most likely, channelized along the shear zone. 

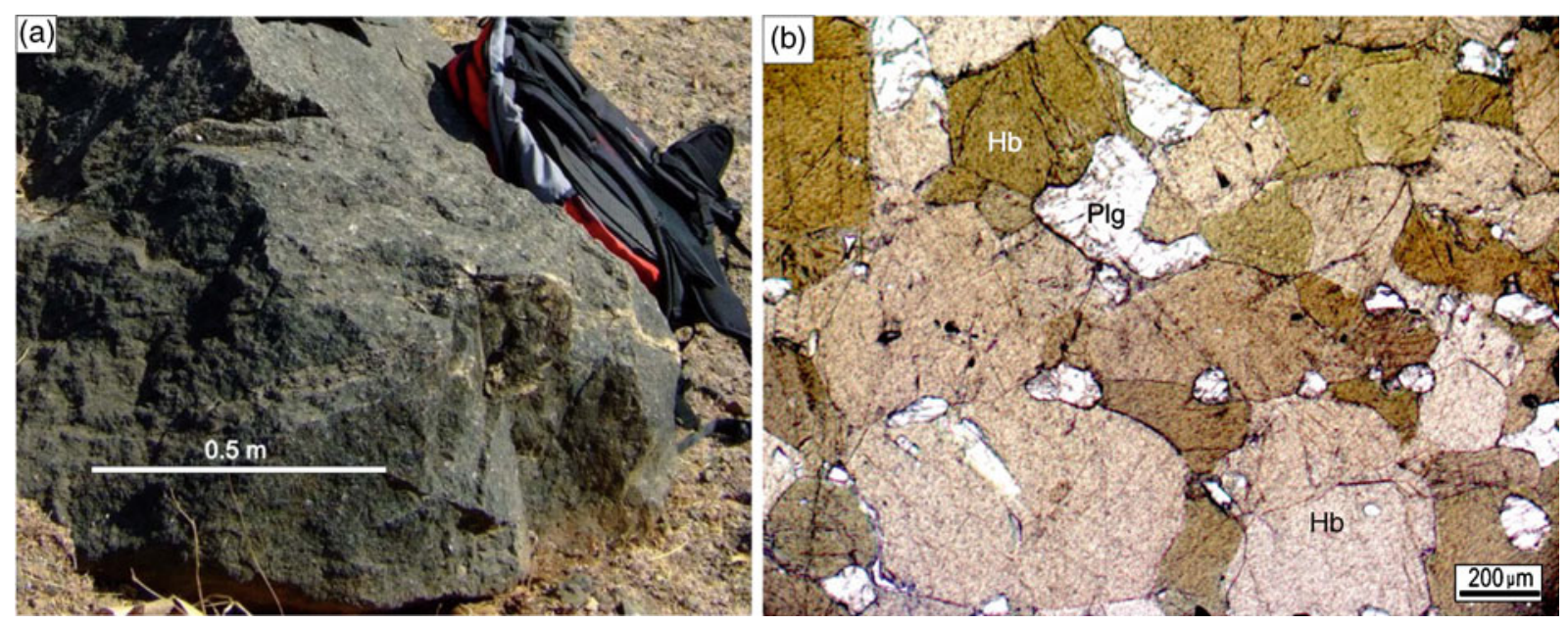

Figure 6. (a) Field photograph showing magmatic appearance of mafic rocks at Kui. (b) Photomicrograph of Kui mafic rock showing thermally equilibrated hornblende grains during amphibolites facies metamorphism.

In Kui area, further south, the mafic rocks occur as minor bodies within the metasediments of Delhi Supergroup rocks and both the sediments and the mafic rocks have been co-folded during subsequent deformation and metamorphism (Biswal et al 2004). The samples from Kui show magmatic appearance, locally with gabbroidic texture (figure 6a) and have completely transformed mineralogy which is now represented by hornblende and sericitic plagioclase. The mineral grain boundaries are straight (figure 6b) indicating thermal re-equilibration under amphibolite facies metamorphism generally recorded in this part of the DFB. These rocks do not show any evidence of shearing or second stage alteration which is prominently seen in Daba rocks.

The felsic and mafic rocks do not show a coherent pattern in the orientation of structural elements (foliation, lineation); in the latter these features are hardly detectable (figure $2 \mathrm{a}, \mathrm{b}$ ). The mafic rocks show more random orientations as compared to well-defined foliation in the felsic rocks in the shear zone. The plunge of lineations in the shear zone is sub-horizontal while it is highly variable $\left(5^{\circ}\right.$ to $\left.62^{\circ}\right)$ in case of mafic rocks. The magnetic fabric orientations (anisotropy of magnetic susceptibility-AMS) (Hrouda 1982, 1993; Borradaile and Henry 1997; de Wall et al 2001) were analyzed to substantiate the structural data and for a better evaluation of the DSZ in terms of relationship between mafic rocks and the shear overprint.

\section{Magnetic fabric characteristics}

For the AMS analyses, oriented hand samples were collected in the field and were drilled in the lab for standard cylinders $(2.5 \mathrm{~cm}$ in diameter and $2.1 \mathrm{~cm}$ in height). Seven samples from the mafic and eight samples from the felsic rocks were analyzed. The AMS data are provided in table 1 . The method uses the directional difference in induced magnetization for fabric characterization. Magnetic susceptibility is measured in low AC-fields (in $300 \mathrm{~A} / \mathrm{m}$, $920 \mathrm{~Hz}$ ) where a linear relationship between magnetic field and magnetization is realized. AGICO kappabridge KLY-4S was used for the measurements, which is of high sensitivity $\left(10^{-8} \mathrm{SI}\right)$ and determines the AMS by measurements in 64 positions for each of three orthogonal sections of the sample. These measurements are used for calculation of the 2nd order tensor of magnetic susceptibility, expressed by an ellipsoid with orthogonal principal axes $\kappa_{\max }>\kappa_{\text {int }}>\kappa_{\min }$.

The Daba felsic rocks (Erinpura Granite) have low magnetic susceptibility (53 to $330 \times 10^{-6} \mathrm{SI}$ ) wherein paramagnetic mica is the predominant magnetic phase. The bulk magnetic susceptibility for the mafic rocks is generally higher and in the range of 300 to $18200 \times 10^{-6}$ SI. Most of the samples are paramagnetic with hornblende as the predominant magnetic phase while a contribution of ferrimagnetic phase, identified as magnetite, is seen in the sample D/15 (table 1). The principal axes of the AMS ellipsoids were plotted in the Schmidt net projection. The long axis of the AMS ellipsoid, $\kappa_{\max }$, is referred to as the magnetic lineation while the short axis, $\kappa_{\min }$, indicates the pole of the magnetic foliation. Further details about the method are given in Tarling and Hrouda (1993). The magnetic fabrics in the felsic rocks reflect a preferred orientation of mica (i.e., biotite) whereby the magnetic lineation is mainly related to the rotation of mica laths around stretched clasts (Siegesmund et al 1995). In the mafic rocks, the magnetic lineation is in the direction of the hornblende mineral 
Table 1. Volume susceptibility ( $\kappa_{\text {mean }}$ in $10^{-6}$ SI units) and magnetic fabric orientation of felsic and mafic rocks from the Daba Shear Zone. Declination (Dec) and Inclination (Inc) of the magnetic lineation $\left(\kappa_{\max }\right)$ and pole to magnetic foliation $\left(\kappa_{\min }\right)$ are listed. For location of samples please refer to figure 2.

\begin{tabular}{|c|c|c|c|c|c|}
\hline Specimen & $\kappa_{\text {mean }}$ & Dec $\kappa_{\max }$ & Inc $\kappa_{\max }$ & $\operatorname{Dec} \kappa_{\min }$ & Inc $\kappa_{\min }$ \\
\hline \multicolumn{6}{|l|}{ Mafic rocks } \\
\hline D-1-1 & 301 & 166 & 46 & 71 & 4 \\
\hline D-1-2 & 364 & 165 & 57 & 72 & 2 \\
\hline D-1-3 & 322 & 349 & 19 & 81 & 4 \\
\hline D-11-2 & 254 & 19 & 11 & 288 & 8 \\
\hline D-11-2-1 & 255 & 17 & 9 & 108 & 2 \\
\hline D-11-2-2 & 297 & 19 & 27 & 287 & 5 \\
\hline D-12-1 & 566 & 242 & 14 & 148 & 17 \\
\hline D-12-2 & 574 & 252 & 30 & 155 & 12 \\
\hline D-13-1 & 612 & 206 & 4 & 113 & 30 \\
\hline D-13-1 & 609 & 207 & 7 & 114 & 30 \\
\hline D-13-2 & 658 & 224 & 22 & 128 & 15 \\
\hline D-14-1 & 975 & 57 & 22 & 307 & 40 \\
\hline D-14-2 & 1007 & 53 & 20 & 304 & 41 \\
\hline D-14-3 & 978 & 39 & 15 & 296 & 39 \\
\hline D-15-1 & 18220 & 220 & 3 & 314 & 46 \\
\hline D-15-2 & 7777 & 41 & 9 & 307 & 21 \\
\hline D-15-3 & 1021 & 220 & 1 & 119 & 86 \\
\hline D-16-1 & 904 & 284 & 51 & 25 & 9 \\
\hline D-16-2 & 939 & 293 & 15 & 25 & 6 \\
\hline \multicolumn{6}{|l|}{ Felsic rocks } \\
\hline DA-1-2-1 & 170 & 32 & 12 & 301 & 7 \\
\hline DA-1-2-2 & 150 & 33 & 11 & 302 & 7 \\
\hline DA1-1 & 166 & 212 & 10 & 120 & 12 \\
\hline DA1-2 & 149 & 214 & 31 & 116 & 13 \\
\hline DA1-3 & 154 & 216 & 27 & 119 & 14 \\
\hline D-3B-1-1 & 269 & 248 & 76 & 138 & 5 \\
\hline D-4-1-1 & 333 & 221 & 62 & 313 & 2 \\
\hline D-4-1-2 & 223 & 228 & 51 & 325 & 5 \\
\hline D-4-2-1 & 275 & 237 & 28 & 147 & 2 \\
\hline D-4-2-2 & 266 & 232 & 42 & 139 & 3 \\
\hline D-5-1 & 53 & 215 & 4 & 120 & 46 \\
\hline $\mathrm{D}-5-2$ & 59 & 22 & 7 & 119 & 45 \\
\hline D-5-3 & 70 & 26 & 3 & 118 & 41 \\
\hline D-6-1 & 87 & 22 & 15 & 112 & 1 \\
\hline D-6-2 & 71 & 23 & 7 & 113 & 2 \\
\hline D-7C-1 & 92 & 37 & 18 & 127 & 1 \\
\hline D-7C-2 & 85 & 34 & 24 & 128 & 9 \\
\hline D-7D-1 & 99 & 207 & 57 & 305 & 5 \\
\hline D-7D-2 & 106 & 209 & 69 & 302 & 2 \\
\hline D-9-1 & 81 & 207 & 10 & 298 & 7 \\
\hline D-9-2 & 95 & 26 & 2 & 296 & 5 \\
\hline SR11-1 & 75 & 12 & 2 & 103 & 27 \\
\hline SR11-2 & 90 & 188 & 7 & 94 & 24 \\
\hline
\end{tabular}

lineation which has also been reported from some other settings (e.g., de Wall et al 2001). The magnetic fabric can be interpreted as preferred growth of hornblende grains during fabric recrystallization under the applied stress.
Magnetic foliation and magnetic lineation for mafic and felsic rocks of the Daba Shear Zone are compared in figure 7 in which $\kappa_{\max }$ as well as $\kappa_{\min }$ show a grouping and indicate predominantly NE-SW trending foliations and subhorizontal to moderately 
(a) Poles of magnetic foliation

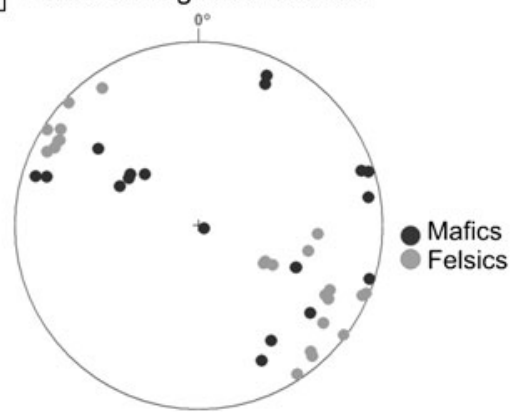

(b) Magnetic Lineation

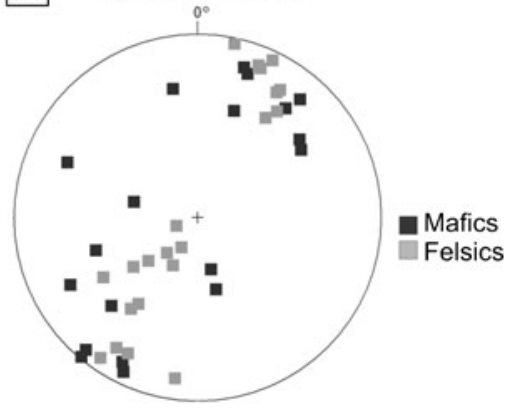

Figure 7. Comparison of magnetic foliations and lineations in the felsic and mafic rocks in Daba Shear Zone. Orientation of magnetic fabrics in Schmidt net projection for the two rock types (sheared Erinpura Granite and mafic rocks).

(a) Presentation of foliation, and (b) lineation parameters. Squares: $\kappa_{\max }$, triangles: $\kappa_{\text {int }}$, dots: $\kappa_{\min }$.

Table 2. Major (wt\% oxide) trace and rare earth element (in ppm) analyses of the Daba and Kui mafic rocks. Major elements analyzed by XRF; trace elements for D-14, Py and Kui-3 by XRF and trace and REE for the rest by ICP-MS. Some critical elemental ratios are also presented. Amph: amphibolites, MG: meta gabbro, MetPx: meta pyroxenite.

\begin{tabular}{|c|c|c|c|c|c|c|c|c|c|c|}
\hline & \multicolumn{7}{|c|}{ Daba } & \multicolumn{3}{|c|}{ Kui } \\
\hline & D-1B & D-12 & D-14 & D-15 & D-16 & PY & Db-2 & Kui-1 & Kui-2 & Kui-3 \\
\hline & Amph & Amph & MG & Amph & Amph & MetPx & MetPx & Amph & Amph & Amph \\
\hline \multicolumn{11}{|c|}{ Oxides (wt\%) } \\
\hline $\mathrm{SiO}_{2}$ & 55.60 & 49.50 & 41.70 & 39.80 & 42.60 & 45.50 & 45.40 & 44.30 & 46.00 & 44.50 \\
\hline $\mathrm{TiO}_{2}$ & 1.04 & 1.14 & 2.68 & 2.95 & 1.99 & 1.91 & 1.73 & 1.71 & 1.20 & 1.72 \\
\hline $\mathrm{Al}_{2} \mathrm{O}_{3}$ & 11.66 & 9.01 & 10.78 & 12.48 & 16.28 & 9.24 & 15.54 & 15.61 & 12.29 & 15.83 \\
\hline $\mathrm{Fe}_{2} \mathrm{O}_{3}$ & 9.38 & 8.30 & 13.70 & 15.41 & 13.39 & 10.05 & 9.29 & 13.71 & 15.83 & 13.68 \\
\hline $\mathrm{MnO}$ & 0.15 & 0.17 & 0.21 & 0.20 & 0.23 & 0.17 & 0.15 & 0.20 & 0.23 & 0.19 \\
\hline $\mathrm{MgO}$ & 7.78 & 12.51 & 11.11 & 10.33 & 6.70 & 11.69 & 7.96 & 7.56 & 9.55 & 7.44 \\
\hline $\mathrm{CaO}$ & 8.39 & 16.49 & 15.76 & 14.86 & 12.35 & 18.31 & 13.61 & 13.05 & 12.10 & 12.53 \\
\hline $\mathrm{Na}_{2} \mathrm{O}$ & 4.54 & 1.15 & 1.79 & 1.76 & 2.99 & 1.64 & 2.39 & 1.68 & 1.45 & 1.75 \\
\hline $\mathrm{K}_{2} \mathrm{O}$ & 0.71 & 0.39 & 0.98 & 1.07 & 1.57 & 0.50 & 1.00 & 0.47 & 0.49 & 0.63 \\
\hline $\mathrm{P}_{2} \mathrm{O}_{5}$ & 0.13 & 0.15 & 0.73 & 0.90 & 0.82 & 0.20 & 0.13 & 0.27 & 0.03 & 0.32 \\
\hline LOI & 0.64 & 1.21 & 0.78 & 1.03 & 1.09 & 0.49 & 2.10 & 0.87 & 0.80 & 1.22 \\
\hline Sum & 100.02 & 100.02 & 100.22 & 100.79 & 100.01 & 99.70 & 99.30 & 99.40 & 99.90 & 99.80 \\
\hline \multicolumn{11}{|c|}{ Trace elements (in ppm) } \\
\hline $\mathrm{Ni}$ & 105 & 102 & 66 & 49 & 41 & 133 & 104 & 57.9 & 82.1 & 55 \\
\hline $\mathrm{V}$ & 200 & 283 & 384 & 488 & 321 & 392 & 324 & 398 & 377 & 376 \\
\hline $\mathrm{Cr}$ & 292 & 436 & 81 & 51 & 73 & 217 & 74 & 261 & 438 & 329 \\
\hline $\mathrm{Co}$ & 39 & 41 & 59 & 53 & 40 & 47 & 48 & 45.3 & 53.8 & 53 \\
\hline $\mathrm{Ga}$ & 18 & 14 & 14 & 16 & 40 & 12 & 17 & 14.2 & 15.7 & 17 \\
\hline $\mathrm{Zr}$ & 103 & 114 & 132 & 147 & 162 & 121 & 154 & 166 & 76 & 102 \\
\hline $\mathrm{Sr}$ & 572 & 589 & 639 & 942 & 1559 & 506 & 1024 & 129 & 75.8 & 134 \\
\hline $\mathrm{Rb}$ & 12 & 14 & 10 & 8 & 43 & 6 & 28 & 11.8 & 12.7 & 28 \\
\hline $\mathrm{Sc}$ & 26 & 76 & - & 41 & 30 & 70 & - & 49.3 & 40.7 & - \\
\hline $\mathrm{Y}$ & 15 & 14 & 37 & 28 & 26 & 21 & 23 & 39.5 & 27.6 & 50 \\
\hline $\mathrm{Nb}$ & 28 & 15 & 27 & 23.4 & 33 & 15 & 18 & 4.21 & 4.44 & 7 \\
\hline $\mathrm{Ba}$ & 331 & 349 & 706 & 637 & 685 & 342 & 402 & 129 & 100 & 194 \\
\hline Hf & 2 & 1.9 & 3 & 3.1 & 2.5 & 2.9 & - & 2.68 & 1.8 & - \\
\hline $\mathrm{Ta}$ & 4.3 & 0.8 & 5 & 1.3 & 1.5 & 0.9 & - & 0.29 & 0.21 & - \\
\hline $\mathrm{Pb}$ & 3.5 & 6.6 & $<4$ & 2.9 & 6 & 3.6 & - & 3.39 & 2.89 & - \\
\hline Th & 5.7 & 1.1 & $<2$ & 1 & 1.7 & 0.5 & - & 0.58 & 0.65 & - \\
\hline $\mathrm{U}$ & 5.7 & 0.4 & - & 0.1 & 0.4 & 0.1 & - & 0.18 & 0.18 & - \\
\hline
\end{tabular}


Table 2. (Continued).

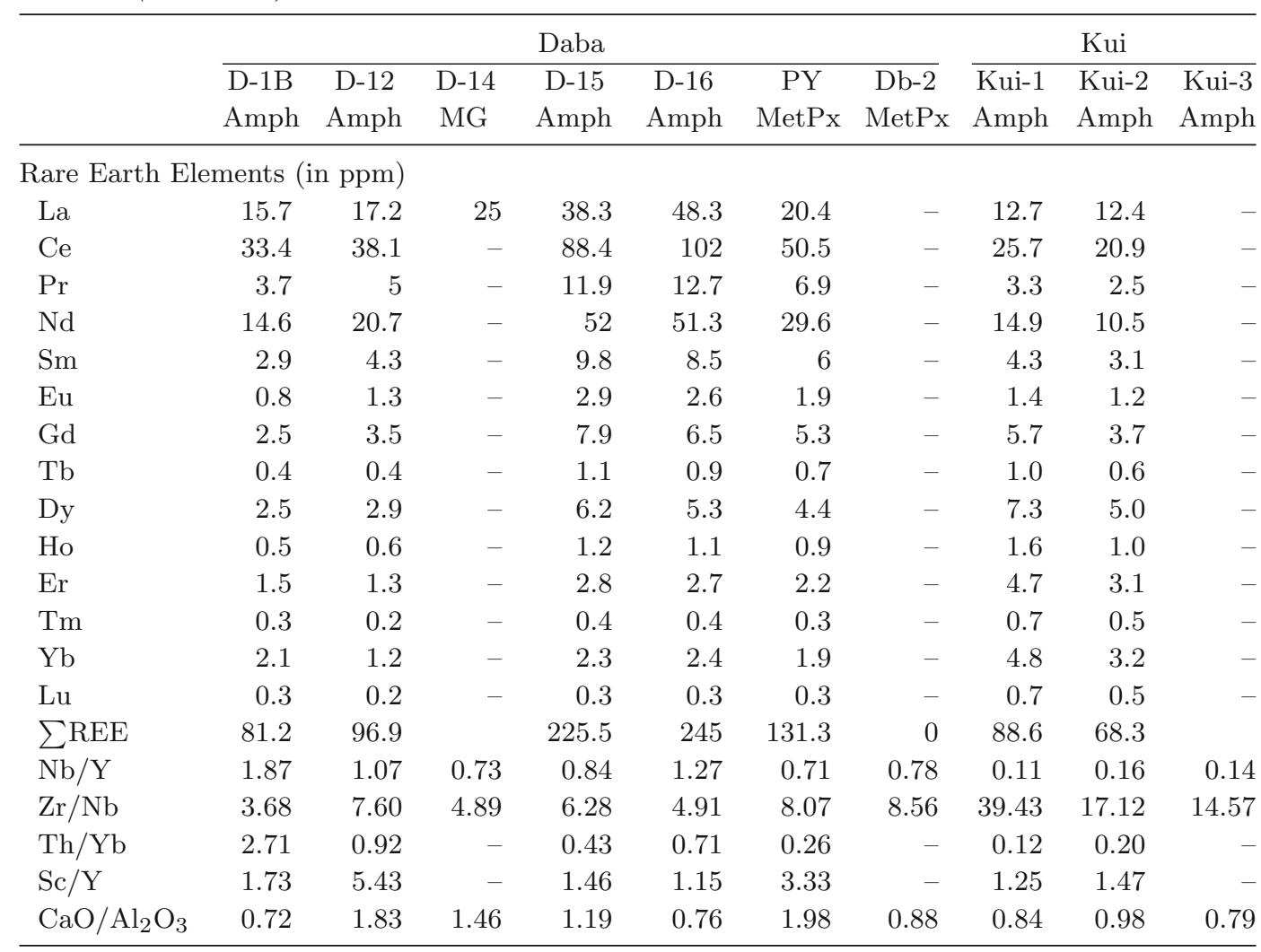

plunging lineation in both the lithological units. However, for the mafic rocks, the magnetic fabric axes are more scattered than in the felsic ones. This is the most pronounced pattern for magnetic foliation. While the $\kappa_{\text {min }}$ axes for felsic rocks yield a well defined cluster to indicate parallel, vertical NE-SW trending foliations, flat to vertical projections of the magnetic foliation poles are realized in the mafic rocks. Two samples (D/1 and D/16), which are from the westernmost part of the sampled area in Daba (figure 2) plot as an outlier and show clear variance in the foliation and lineation orientation (table 1). The magnetic fabric analysis further substantiates that both the rock types have undergone the same shear deformation. Strain is concentrated in the quartzo-feldspathic rocks and structures in the mafic rocks are more variable and partially cryptic in nature.

\section{Geochemistry}

\subsection{Analytical methods}

We have analyzed seven mafic rock samples from the Daba Shear Zone and three from Kui area (figure 1a). Major oxides and some trace element compositions (Cr, Co, Ni, Zn, Zr, Sr and Rb) were measured on fused pellets by Philips PW 2400
X-ray fluorescence spectrometer. Rare earth elements and some other trace elements $(\mathrm{V}, \mathrm{Nb}, \mathrm{HF}$, $\mathrm{Y}$, Ta, Sc, Th, Ga, Ba, Pb) were analyzed by Laser Ablation Inductively Coupled Plasma Mass Spectrometer (LA ICP-MS), at the GeoZentrum Nordbayern, University of Erlangen, Germany. For ICP-MS analysis each pellet was ablated five times along $\sim 900 \mu \mathrm{m}$ long lines with a repetition rate of $20 \mathrm{~Hz}$, a crater size of $40 \mu \mathrm{m}$ and a scan speed of $40 \mu \mathrm{m} / \mathrm{s}$. The laser energy was $0.51-$ $0.71 \mathrm{~mJ}$ ( $\sim 40-56 \mathrm{~J} / \mathrm{cm}^{2}$ energy density) following the method prescribed in Brätz and Klemd (2002). Reported accuracies are up to 5\% for major and trace elements and up to $7 \%$ for rare earth elements. For loss on ignition (LOI) estimation, the dry sample powders were heated in an oven for eight hours and the difference in mass was calculated as the 'volatiles' or LOI. The geochemical data on Daba and Kui mafic rocks are given in table 2 .

\subsection{Major and trace element geochemistry}

The Daba mafic rock samples show a large variation in $\mathrm{SiO}_{2}$ which ranges from 39.8 to $49.5 \%$ except sample D1b, which has anomalous high value of $55.6 \%$. The high silica content is most likely a result of fine felsic intercalations (thin feldspar-rich bands) present in the sample. $\mathrm{TiO}_{2}$ 

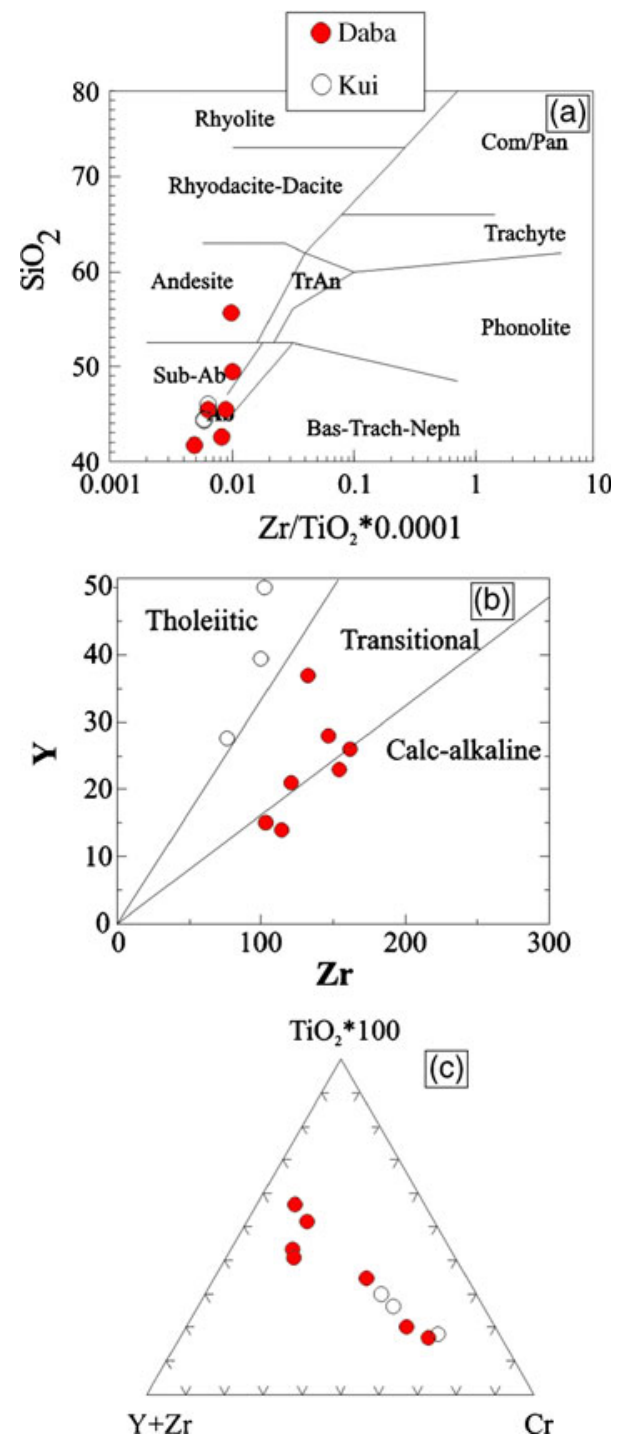

Figure 8. Geochemical discrimination of Daba and Kui mafic rocks (major oxides as wt\% and trace elements as ppm). (a) $\mathrm{SiO}_{2}-\mathrm{Zr} / \mathrm{TiO}_{2}$ diagram (Winchester and Floyd 1977) showing classification as sub-alkaline basalt. (b) $\mathrm{Y}-\mathrm{Zr}$ discrimination diagram (Barrett and MacLean 1994) showing well defined tholeiitic affinity (high $\mathrm{Y} / \mathrm{Zr}$ ) for Kui samples while Daba samples are transitional to slightly calc-alkaline. (c) $\mathrm{TiO}_{2}-\mathrm{Y}+\mathrm{Zr}-\mathrm{Cr}$ trilinear diagram showing tholeiitic trend for Daba and Kui mafic rocks (trend lines after Davies et al 1979).

contents vary from 1.01 to $2.98 \%$ and $\mathrm{MgO}$ from 6.7 to $12.51 \%$. $\mathrm{CaO}, \mathrm{Na}_{2} \mathrm{O}$ and $\mathrm{K}_{2} \mathrm{O}$ contents are highly variable and range from 8.39 to $18.31 \%, 1.15$ to $4.54 \%$ and 0.39 to $1.57 \%$, respectively, which can be attributed to their variable mobilization during post-crystallization processes. Considering the moderate-to-high $\mathrm{Fe}_{2} \mathrm{O}_{3}$ contents, the rocks can be called as tholeiites to high $\mathrm{Mg}$ tholeiites. The Kui samples are more homogenous in terms of elemental concentrations such as $\mathrm{SiO}_{2}(44.3$ to $46 \%), \mathrm{TiO}_{2}$ (1.20 to $1.73 \%), \mathrm{MgO}$ (7.44 to $9.55 \%), \mathrm{CaO}$ (12.10 to $13.61 \%), \mathrm{Na}_{2} \mathrm{O}(1.45$ to $1.75 \%)$ and $\mathrm{K}_{2} \mathrm{O}(0.47$ to
$0.63 \%$ ) and show some overlap with Daba samples. The Daba samples have moderate-to-high concentrations of HFS elements, such as Zr, Y and Nb, which vary from 103 to $162 \mathrm{ppm}, 15$ to $37 \mathrm{ppm}$ and 15 to $27 \mathrm{ppm}$, respectively. Kui samples have similar Zr, higher $\mathrm{Y}$ and lower $\mathrm{Nb}$ abundances as compared to Daba rocks. Such distinctions are spelled out in significant differences in the critical trace elemental ratios (table 2).

Since the rocks are deformed and variably altered, some of the elements especially alkalis, alkaline earths and large ion lithophile elements may have been mobile and may not represent pristine compositions. Moderate to low LOI values (2.1 to $0.49 \%$ ) preclude any large-scale alteration effect. In case of basic rocks the REE, $\operatorname{HFSE}(\mathrm{Ti}, \mathrm{Zr}$, $\mathrm{Y}, \mathrm{Nb}, \mathrm{Hf}, \mathrm{P}, \mathrm{Th}$, etc.) and transition metals (Sc, $\mathrm{V}, \mathrm{Cr}$ ) are considered generally immobile during low temperature alteration processes (Camire et al 1995; Kerrich et al 1998) and can be used for petrogenetic interpretations. Considering the stability fields of mineral assemblages it seems likely that the Daba and Kui rocks may have undergone up to lower amphibolite facies metamorphism. Therefore, the geochemical trends have been evaluated against $\mathrm{Zr}$ and only the relatively immobile elements have been considered for classification and petrogenetic interpretations. The Kui samples have low $\mathrm{Nb} / \mathrm{Y}$ ratios $(<1)$ and indicate tholeiitic affinity while Daba samples $(\sim 1)$ show a little overlap with alkaline rocks (Pearce and Gale 1977). The samples were plotted in the immobile elements based classification diagrams (figure 8). In the $\mathrm{SiO}_{2}-\mathrm{Zr} / \mathrm{TiO}_{2}$ classification diagram of Winchester and Floyd (1977) all the samples classify as sub-alkaline basalt except the sample (D1-B) which plots in the field for andesite on account of higher silica (figure 8a). In the $\mathrm{Y}-\mathrm{Zr}$ discrimination diagram (Barett and MacLean 1994) the Kui samples define a tholeiitic affinity (high Y/Zr) while Daba samples are transitional to slightly calc-alkaline (figure 8b). The tholeiitic character of the samples is clearly depicted in the $\mathrm{TiO}_{2}-\mathrm{Y}+\mathrm{Zr}-\mathrm{Cr}$ diagram of Davies et al (1979) where all the samples plot along a tholeiitic trend (figure 8c). This diagram is based on immobile elements and can discriminate tholeiitic and calc-alkaline trends analogous to conventional AFM diagram.

To understand the elemental behaviour during crystallization, some critical major and trace elements were plotted against $\mathrm{Zr}$ (figure 9), which is highly immobile and incompatible, and can proxy for $\mathrm{MgO}$ in evaluating fractionation process. Geochemical data for other areas of Phulad Ophiolite, from Phulad-Barr-Jetgarh sector (Volpe and Macdougall 1990) and for northern, central and southern sectors (Khan et al 2005, using complete dataset provided by the authors) are also shown 

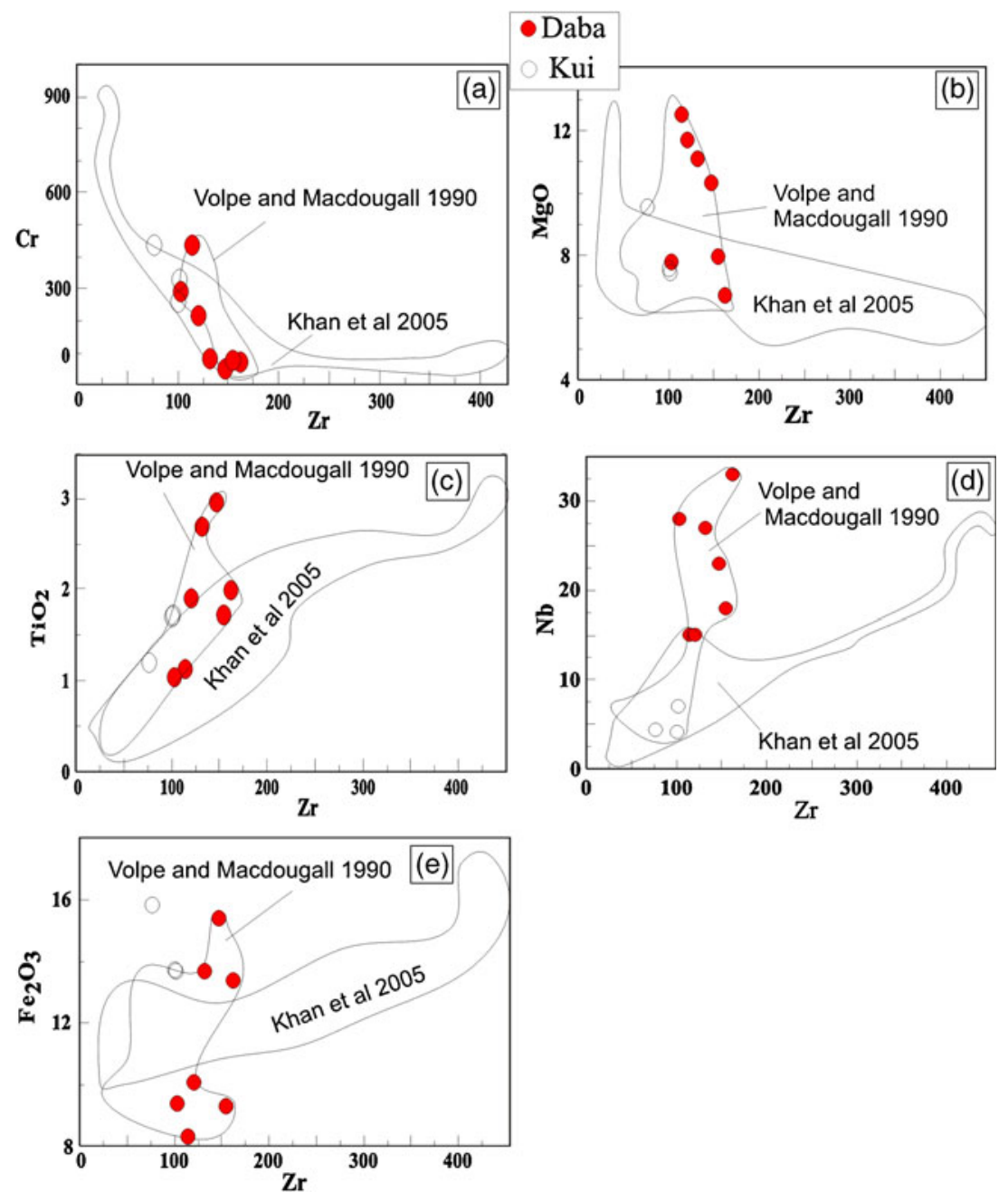

Figure 9. Bivariate diagrams showing behaviour of some critical elements against Zr in Daba and Kui mafic rocks. Normal fractionation tends are discernible in inverse correaltion of $\mathrm{Zr}$ with $\mathrm{Cr}$ (a) and $\mathrm{MgO}$ (b) while a covariance is seen in $\mathrm{Zr}-$ $\mathrm{TiO}_{2}$ (c) and $\mathrm{Zr}-\mathrm{Nb}(\mathbf{d})$ pairs. The behaviour of $\mathrm{Fe}_{2} \mathrm{O}_{3}$ is erratic, however, a faint covariance with $\mathrm{Zr}$ can be seen (e). For comparison fields of Phulad-Barr-Jetgarh of Volpe and Macdougall (1990) and different sectors of Phulad Ophiolite Suite of Khan et al (2005) have also been shown.

as respective fields onto the bivariate plots (figure 9 ). Stray samples were not considered while drawing the fields for Volpe and Macdougall (1990) and Khan et al (2005). The Daba and Kui samples show a general correspondence with the PhuladBarr-Jetgarh samples (figure 9a-e). Notwithstanding the alteration effects, the Daba and Kui samples define normal fractionation trends, demonstrated as inverse correlation between $\mathrm{Zr}-\mathrm{Cr}$ (figure 9a), $\mathrm{Zr}-\mathrm{MgO}$ (figure 9b) and covariance between $\mathrm{Zr}-\mathrm{TiO}_{2}$ (figure $9 \mathrm{c}$ ) and $\mathrm{Zr}-\mathrm{Nb}$ (figure 9d) pairs. Behaviour of $\mathrm{Fe}_{2} \mathrm{O}_{3}$ is rather erratic, although a faint covariance with $\mathrm{Zr}$ is discernible in case of Daba samples (figure 9e). A positive correlation between $\mathrm{Zr}$ and $\mathrm{Y}$ is already shown in figure $8(\mathrm{~b})$. Such correlations of $\mathrm{Zr}$ with other elements indicate derivation of these rocks through fractional crystallization process. A regular decrease in $\mathrm{CaO} / \mathrm{Al}_{2} \mathrm{O}_{3}$ with progressive fractionation indicates that olivine and pyroxene were the main crystallizing phases (table 2 ).

The primitive mantle normalized multi-element spider diagrams for Daba mafic rocks show positive $\mathrm{Ba}$ anomaly, minor peak for $\mathrm{Sm}$ and negative anomalies for Th and Hf (figure 10a). The odd sample (D/16), however, shows higher abundance levels of LIL elements and peaks for Th and Ta. The Kui samples show much lower enrichment levels for LILE and LREE $(\sim 20)$ and flat patterns towards the compatible element end of the diagram (figure 10b). The patterns show peaks for LIL elements $(\mathrm{K}, \mathrm{Rb}, \mathrm{Ba})$ and $\mathrm{La}$, negative Th anomaly and characteristic Nb-Ta trough. Although, both the datasets show enrichment in LILE and LREE, notable differences in the enrichment levels, shape and pattern underline distinct source characteristics for the Daba and Kui samples. The Daba patterns show a similarity with the E-type MORB 

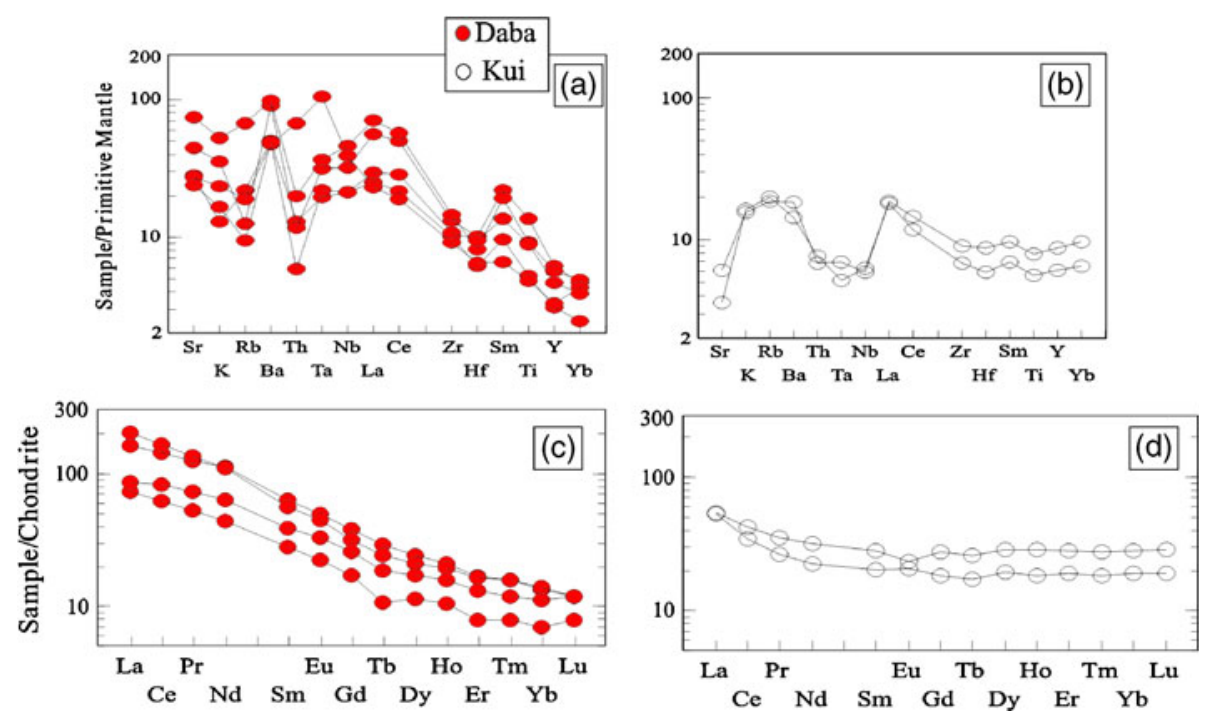

Figure 10. Primitive Mantle normalized trace element and chondrite normalized REE diagrams for Daba and Kui samples (normalizing values after Sun and McDonnough 1989). Trace element spider-diagrams for Daba (a) and Kui (b) showing enrichment in LIL elements and Nb anomaly in Kui samples. Note higher levels of enrichment and slope towards compatible end members in case of Daba (a) while Th anomaly and Nb-Ta trough can be seen in case of Kui data (b). Chondrite normalized REE patterns for Daba (c) and Kui (d) samples showing distinct patterns. Note a significant LREE enrichment and fractionated pattern for Daba samples (c) while Kui samples define insignificant LREE enrichment and flat HREE pattern $(\mathbf{d})$.

while Kui samples show continental signatures and patterns in calc-alkaline rocks (Wilson 1989). The differences are further outlined in the chondrite normalized REE patterns (figure 10c, d). The Daba patterns show steep slopes and significant LREE enrichment, indicated by La abundances 66 to 204 times the chondrite and $(\mathrm{La} / \mathrm{Sm})_{\mathrm{N}} \sim 3$ to 3.5 (figure 10c). Absence of any noticeable Eu anomaly further supports the contention that plagioclase was not a major fractionating phase. Such patterns are clearly distinct from the N-MORB, which are characterized by LREE depletion. Although REE are generally immobile, crustal metamorphism and anatexis may lead to enriched LREE trends. Such a possibility seems unlikely in the light of observed negative Th anomalies because crustal melts would also result in associated Th enrichment. Although Kui samples have prominent $\mathrm{Nb}$ negative anomaly, in the absence of corresponding LREE enrichment, this can be regarded as an intrinsic characteristic and not related to any post-crystallization modifications. Depleted HREE [(La/Lu $)_{\mathrm{N}} 5.61$ to 17.25$]$ patterns suggest garnet as a refractory phase in the source of these rocks. Residual garnet would result in HREE depletion due to their preferential retention (Wilson 1989). If partial melting is fairly extensive $(>10 \%)$ the REE should not be fractionated from each other during melting and therefore the elemental ratios of critical REE (La/Sm, La/Yb, Ce/Yb and $\mathrm{La} / \mathrm{Ce}$ ) should reflect the ratios in the mantle source (e.g., Rollinson 1993). However, only light REE are truly incom- patible and thus only La/Ce ratio is likely to be diagnostic of the source composition (Wilson 1989; Torres-Alvarado et al 2003). The Kui REE patterns are almost flat with a minor LREE enrichment $\left[(\mathrm{La} / \mathrm{Sm})_{\mathrm{N}}=1.7\right.$ to 2.4$]$ and unfractionated HREE trends. Such patterns indicate relatively higher degree of melting as compared to the Daba samples.

\section{Discussion and interpretation}

The data presented in the preceding sections characterize the Daba mafic body as a shear bound (strike-slip kinematics) ensemble of mafic rocks with subalkaline affinity. The strain is highly localized within the felsic rocks (mylonitized Erinpura Granite) and in garnet mica schist along the contact with mafic body. Within the magmatic body the shear deformation is seen only at few places, especially in feldspar rich parts. This strain partitioning gives an overall unstrained appearance to the mafic rocks which generally do not show any field evidence of deformation. However, the magnetic fabric study has underlined a general correspondence of structural elements in both the lithologies and thus identifies the magmatic textures as shear relicts. Despite the preserved magmatic texture, both the Daba and Kui mafic rocks have completely transformed mineralogies. While in the Kui rocks a single stage fabric re-equilibration under amphibolite facies conditions is recognized, the Daba rocks 
show at least two phases of fabric transformation (amphibolite facies and lower amphibolite to greenschist facies), wherein the second stage is related to the shear deformation.

Fluid mobilization during shearing and lower amphibolites facies metamorphism can potentially affect the geochemical characteristics including relatively immobile elements. Crustal fluids can induce prominent $\mathrm{Nb}$ negative anomalies. In the present case, the geochemical signatures do not seem to be significantly modified as shown in consistent REE patterns, absence of Ce anomaly (Polat and Hofmann 2003) and well-defined fractionation trends. Good binary correlations of $\mathrm{Zr}$ with other HFSE underline fractionation as the main process in the evolution of Daba and Kui rocks (figure 9). The Primitive Mantle normalized patterns for Daba and Kui are distinct from each other and show consistency within both the groups (figure 10a, b). Enrichment in LREE, K, Rb, $\mathrm{Ba}$ and $\mathrm{Th}$ and depletion in $\mathrm{Nb}$ are considered typical continental signatures, characteristic of oceanic or within plate settings which are enriched in incompatible elements (Wilson 1989). Such characteristics of Kui samples indicate a significant 'continental' signature. Such patterns can also result from interaction with subduction fluids, from sediment mixing or due to crustal fluids during metamorphism. The Daba rocks show much higher degree of LREE enrichment, however, any crustal input seems unlikely on account of prominent Th and $\mathrm{Rb}$ depletion and absence of any negative $\mathrm{Nb}$ anomaly. These features can be interpreted as inherited from an enriched lithospheric mantle source.

To evaluate possible contribution from mantle source and the subduction component, Pearce (1983), Pearce and Peate (1995) proposed M/Yb$\mathrm{Nb}(\mathrm{Ta}) / \mathrm{Yb}$ plots where $\mathrm{M}$ is an incompatible element of interest. The diagrams are based on the assumption that subduction-related enrichment in ' $M$ ' would result in displacement of the data from the 'mantle array'. More recently, Pearce (2008) has demonstrated the suitability of $\mathrm{Th}-\mathrm{Nb}$ and $\mathrm{Ti}-\mathrm{Yb}$ plots in evaluating subduction/nonsubduction character and melting depth and temperature, respectively. In these diagrams majority of ocean floor basalts plot within a diagonal MORB-OIB array in the $\mathrm{Nb} / \mathrm{Yb}-\mathrm{Th} / \mathrm{Yb}$ plot. Daba and Kui samples plot in two distinct fields in this diagram (figure 11a), corresponding to E-MORB and N-MORB, respectively. The Kui samples are marginally displaced above the array while Daba samples plot along a dispersion axis oblique to the array. Such trends indicate a subduction or continental margin setting. In the $\mathrm{TiO}_{2} / \mathrm{Yb}-\mathrm{Nb} / \mathrm{Yb}$ diagram, the N-MORB affinity for Kui and E-MORB for Daba are shown
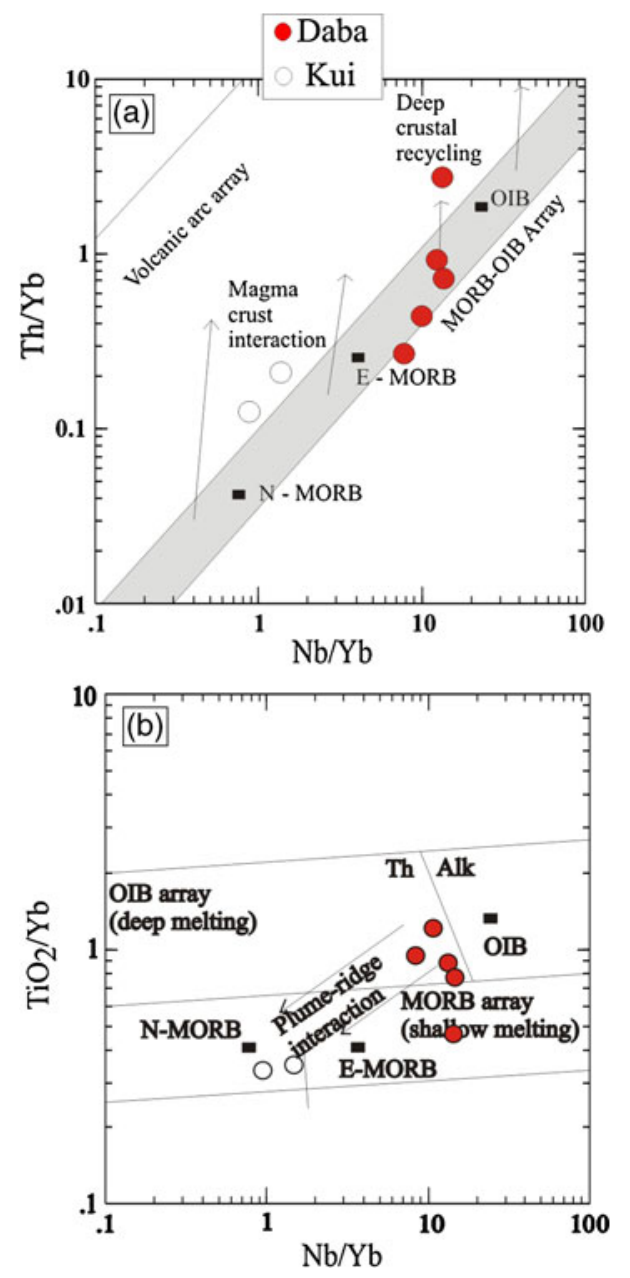

Figure 11. Tectonic discrimination and source characterization of Daba and Kui mafic rocks (Pearce 2008). (a) Nb/Yb$\mathrm{Th} / \mathrm{Yb}$, and (b) $\mathrm{TiO}_{2} / \mathrm{Yb}-\mathrm{Nb} / \mathrm{Yb}$ diagrams showing distinct mantle sources for Daba and Kui samples.

(figure 11b) on account of higher $\mathrm{Nb}$ and $\mathrm{TiO}_{2}$ abundances in the latter.

Differences in mantle source characteristics between Daba and Kui samples cannot be explained in terms of mantle heterogeneity which seems unlikely on such a micro scale. These characteristics, however, can be explained through different stages of ophiolite development as detailed in Shervais (2001). Most of the tectonic models for ophiolite formation and evolution propose that ophiolites generally form during early stages of subduction of oceanic lithosphere (Stern and Bloomer 1992; Shervais 2001). Mafic rocks of Phulad Suite are juxtaposed with shallow water sediments in the east followed by platformal sediments and then continental slope sediments in the further east indicating gradual thickening of the crust from west to east and an eastward subduction (Khan et al 2005). We relate the development of Daba and Kui mafic rocks to this eastward subduction and 
propose a model that envisages influx of fluids from the subducting slab into the mantle wedge to initiate melting of the lithospheric mantle to produce LILE enriched melts (Daba rocks). A lower degree of melting is also indicated by highly LREE fractionated patterns. This explains the E-MORB characteristics of Daba samples where enrichment can be related to the addition from fluids. Enrichment in LILE (K, Rb, Cs, Ba) and LREE and depletion in HFSE ( $\mathrm{Ti}, \mathrm{Nb}, \mathrm{Ta}, \mathrm{Hf}$ ) in response to aqueous fluids expelled during subduction are common characteristics of subduction zone ophiolites (see Shervais 2001, for a review). Depletion in HFSE can be caused by larger fractions of partial melting. Further flow of new MORB-source asthenosphere into the wedge beneath the extending lithosphere would initiate melting of previously depleted, 'refractory', asthenosphere (stranded within the zone of melting) under increasing flux of subduction related fluids. Consequently the melts are strongly depleted in HFSE (Ti, Nb, Ta, Hf) and HREE compared to oceanic basalts. Large flux of slab-derived melts required to lower the solidus in the refractory mantle would also result in addition of LILE and LREE, reflected in LILE enriched and HFSE depleted patterns (Shervais 2001). The undifferentiated and flat REE patterns, anomaly for Th and $\mathrm{Nb}-\mathrm{Ta}$ trough, etc., in Kui rocks can be explained through higher degree of melting of the 'refractory' asthenospheric mantle. This model also explains the $\mathrm{Zr} / \mathrm{Nb}$ variability (table 2) between Daba and Kui samples, possibly resulting from selective enrichment in $\mathrm{Zr}$. However, this model is valid for ophiolites not affected by post crystallization modifications. The $(\mathrm{Gd} / \mathrm{Yb}) \mathrm{n}$ of $\geq 1$ for Daba and Kui indicate that the mantle source was at a depth of garnet stability (Hirschmann and Stolper 1996).

Distribution of POS mafic-ultramafic rocks along the western margin and in the foreland of the DFB seems to be largely controlled by the major NE-SW trending shear system of the WMF. The Daba Shear Zone shows a similar structural trend and also marks the southern extension of a bundle of shear zones that have been recognized in the Sirohi area (Roy and Sharma 1999). On a larger scale this shear system is most likely a consequence of late-Neoproterozoic $(775 \pm 26 \mathrm{Ma}$, Just et al 2011) transpression in the foreland of the DFB. This implies a significant structural imprint along the western margin of the DFB following the Erinpura thermal event $(\sim 850 \mathrm{Ma})$, the latter regarded as a late syn-orogenic to post-orogenic phase of the Delhi orogeny. Tectonic significance of this deformation event is still not known and the structural relationship between Daba Shear Zone and the POS is also inconclusive, for which efforts are underway.

\section{Acknowledgements}

The authors are thankful to Dr Helene Brætz and Melanie Hertel (both from GeoZentrum Nordbayern, Erlangen) for support in ICPMS and XRF analyses. Dr M Shamim Khan is thanked for providing geochemical dataset on Phulad ophiolite samples. Constructive comments from three anonymous reviewers have been helpful in improving the manuscript. Authors also thank the handling editor (Prof. Talat Ahmad) for his valuable comments and suggestions. They acknowledge partial support from DST, New Delhi (ESS/16/182/2002).

\section{References}

Barett T G and MacLean W H 1994 Chemostratigraphy and hydrothermal alteration in exploration for VHMS deposits in greenstone and younger volcanic rocks; In: Alteration and alteration processes associated with ore forming systems (ed.) Lentz D R, Geol. Assoc. Canada Short Course Notes 11 433-467.

Biswal T K, Sarkar S, Pal U and Chakraborty U 2004 Pseudotachylites of the Kui-Chitraseni Shear Zones of the Precambrian Aravalli Mountain, Rajasthan; J. Geol. Soc. India 64 325-335.

Borradaile G J and Henry B 1997 Tectonic application of magnetic susceptibility and its anisotropy; Earth Sci. Rev. 42 49-93.

Brätz H and Klemd R 2002 Analysis of Rare Earth Elements in Geological Samples by Laser Ablation - Inductive Couple Plasma Mass Spectroscopy (LA-ICP-MS); Agilent Technologies Online Pubilcation No 6.

Camire G, La Fleche M R and Jenner G A 1995 Geochemistry of pre-Taconian mafic volcanism in Humber Zone of northern Appalachian; Chem. Geol. 119 55-77.

Choudhary A K, Gopalan K and Sastry C A 1984 Present status of geochronology of Precambrian rocks of Rajasthan; Tectonophys. 105 131-140.

Dalziel I W D 1991 Pacific margins of Laurentia and East Antarctica as a conjugate rift pair: Evidence and implications for an Eocambrian supercontinent; Geology 19 598-601.

Davies J F, Grant R W E and Whitehead R E S 1979 Immobile trace elements and Archaean volcanic stratigraphy in the Timmins mining area, Ontario, Canada; Earth Sci. 16 305-311.

Deb M, Thorpe R I, Kristic D, Corfu F and Davis D W 2001 Zircon $\mathrm{U}-\mathrm{Pb}$ and galena $\mathrm{Pb}-\mathrm{Pb}$ isotope evidence for an approximate $1.0 \mathrm{Ga}$ terrane constituting the western margin of the Aravalli-Delhi orogenic belt, northwestern India; Precamb. Res. 108 195-213.

de Wall H, Greiling R O and Fouad Sadek M 2001 Postcollisional shortening in the late Pan African Hamisana high strain zone, SE Egypt: Field and magnetic fabric evidence; Precamb. Res. 107 179-194.

Ghosh S K, Hazra S and Sengupta S 1999 Planar, non-planar and refolded sheath folds in the Phulad Shear Zone, Rajasthan, India; J. Struct. Geol. 21 1715-1729.

Gupta S N, Arora Y K, Mathur R K, Iqballuddin, Prasad B, Sahai T N and Sharma S B 1980 Lithostratigraphic map of the Aravalli Region; Geol. Surv. India, Kolkata. 
Gupta S N, Arora Y K, Mathur R K, Iqballuddin, Prasad B, Sahai T N and Sharma S B 1997 The Precambrian geology of the Aravalli Region; southern Rajasthan and northeastern Gujarat; Geol. Surv. India Memoir $123262 \mathrm{p}$.

Heron A M 1953 Geology of Central Rajputana; Geol. Surv. India Memoir $79339 \mathrm{p}$.

Hirschmann M M and Stolper E M 1996 A possible role for garnet pyroxenite in the origin of the 'garnet signature' in MORB; Contrib. Mineral. Petrol. 124 185-208.

Hrouda F 1982 Magnetic anisotropy of rocks and its application in Geology and Geophysics; Geophys. Surv. 5 $37-82$.

Hrouda F 1993 Theoretical models of magnetic anisotropy to strain relationship; Phys. Earth Planet. Inter. $\mathbf{7 7}$ $237-249$.

Just J, Schulz B, Jourdan F, de Wall H and Pandit M K 2011 Microstructure controlled monazite EPMA age constraints on the deformation and thermal events in the Erinpura Granites, NW India; Gondwana Res. 19 402-412.

Khan M S, Smith T E, Raza M and Huang J 2005 Geology, geochemistry and tectonic significance of maficultramafic rocks of Mesoproterozic Phulad Ophiolite Suite of South Delhi Fold Belt, NW Indian shield; Gondwana Res. 8 553-566.

Kerrich R W, Wyman D, Fan J and Bleeker W 1998 Boninite series: Low-Ti tholeiite associations from the $2.7 \mathrm{Ga}$ Abitibi greenstone belt; Earth Planet. Sci. Lett. 164 303-316.

Li Z X, Bogdanova S V, Collins A S, Davidson A, de Waele B, Ernst R E, Fitzsimons I C W, Fuck R A, Gladkochub D B, Jacobs J, Karlstrom K E, Lu S, Natapov L M, Pease V, Pisarevsky S A, Thrane K and Venikovsky V 2008 Assembly, configuration and break-up history of Rodinia: A synthesis; Precamb. Res. 160 179-210.

Meert J G and Torsvik T H 2003 The making and unmaking of a supercontinent: Rodinia revisited; Tectonophys. $\mathbf{3 7 5}$ 261-288.

Pandit M K, Sial A N, Jamrani S S and Ferreira V P 2001 Carbon isotopic profile across the Bilara Group rocks of trans-Aravalli Marwar Supergroup in Western India: Implications for Neoproterozoic-Cambrian transition; Gondwana Res. 4 387-394.

Pandit M K, Carter L M, Ashwal L D, Tucker R D, Torsvik T H, Jamtveit B and Bhushan S K 2003 Age, petrogenesis and significance of $1 \mathrm{Ga}$ granitoids and related rocks from the Sendra area, Aravalli Craton, NW India; J. Asian Earth Sci. 22 363-381.

Pareek H S 1984 Pre-Quaternary geology and mineral resources of northwestern Rajasthan; Geol. Surv. India Memoir 11599.

Pearce J A 1983 Role of subcontinental lithosphere in magma genesis at active continental Margins; In: Continental Basalts and Mantle Xenoliths (eds) Hawkeswort C J and Norry M J, Shiva Nantwich, 230-249.

Pearce J A 2008 Geochemical fingerprinting of oceanic basalts with application to ophiolite classification and the search for Archean oceanic crust; Lithos 100 14-48.

Pearce J A and Gale D M 1977 Identification of ore deposition environment from trace element geochemistry; Geol. Soc. London Spec. Publ. 7 14-29.

Pearce J A and Peate D W 1995 Tectonic implications of the composition of volcanic arc magmas; Ann. Rev. Earth Planet. Sci. 23 251-285.
Polat A and Hofmann A W 2003 Alteration and geochemical patterns in the 3.7-3.8 Ga Isua Greenstone Belt, west Greenland; Precamb. Res. 126 197-218.

Rollinson H R 1993 Using geochemical data: Evaluation, presentation, interpretation; Longman Scientific Technical 344.

Roy A B and Jakhar S R 2002 Geology of Rajasthan (Northwest India) - Precambrian to Recent; Scientific Publishers (India), Jodhpur, 421.

Roy A B and Kröner A 1996 Single zircon evaporation ages constraining the growth of the Archaean Aravalli craton, northwestern Indian shield; Geol. Mag. 133 333-342.

Roy A B and Sharma K K 1999 Geology of the region around Sirohi town, western Rajasthan - story of Neoproterozoic evolution of the Trans-Aravalli crust; In: Geological evolution of western Rajasthan; (ed.) Paliwal B S, Scientific Publishers (India), Jodhpur 19-33.

Sarkar S and Biswal T K 2005 Tectonic significance of fissure veins associated with pseudotachylites of the KuiChitraseni Shear Zone, Aravalli Mountain, NW India; Gondwana Res. 8 277-282.

Sengupta S and Ghosh S K 2004 Analysis of transpressional deformation from geometrical evolution of mesoscopic structures from Phulad shear zone, Rajasthan, India; J. Struct. Geol. 26 1961-1976.

Shervais J W 2001 Birth, death, and resurrection: The life cycle of suprasubduction zone ophiolites; Geochem. Geophys. Geosyst. 2 2000GC000080.

Siegesmund S, Ullemeyer K and Dahms M 1995 Control on magnetic rock fabrics by mica preferred orientation: A quantitative approach; J. Struct. Geol. 17 1601-1613.

Stern R J and Bloomer S H 1992 Subduction zone infancy: Examples from the Eocene Izu-Bonin-Mariana and Jurassic California arcs; Geol. Soc. Am. Bull. 104 1621-1636.

Sun S-S and McDonough W F 1989 Chemical and isotopic systematics of oceanic basalts: Implications for mantle composition and processes. In: Magmatism in the Ocean Basins; (eds) Saunders A D and Norry M J, Geol. Soc. London Spec. Publ. 313-345.

Tarling D H and Hrouda F 1993 The Magnetic Anisotropy of Rocks (London: Chapman \& Hall), 217 p.

Torres-Alvarado I S, Verma S P, Palacios-Berruete H, Guevara M and González-Castillo O Y 2003 DC_Base: A database system to manage Nernst distribution coefficients and its application to partial melting modelling; Comput. Geosci. 29 1191-1198.

van Lente B, Ashwal L D, Pandit M K, Bowring S A and Torsvik T H 2009 Neoproterozoic hydrothermally altered basaltic rocks from Rajasthan, northwest India: Implications for late Precambrian tectonic evolution of the Aravalli craton; Precamb. Res. 170 202-222.

Volpe A M and Macdougall J D 1990 Geochemistry and isotopic characteristics of mafic (Phulad Ophiolite) and related rocks in the Delhi Supergroup, Rajasthan, India: Implications for the rifting in the Proterozoic; Precamb. Res. 48 167-191.

Wiedenbeck M, Goswami J N and Roy A B 1996 Stabilization of the Aravalli Craton of the northwestern India at $2.5 \mathrm{Ga}$ : An ion microprobe zircon study; Chem. Geol. 129 $325-340$.

Wilson M 1989 Igneous Petrogenesis. Unwin Hyman 466.

Winchester J A and Floyd P A 1977 Geochemical discrimination of different magma series and their differentiation products using immobile elements; Chem. Geol. 20 $325-343$. 